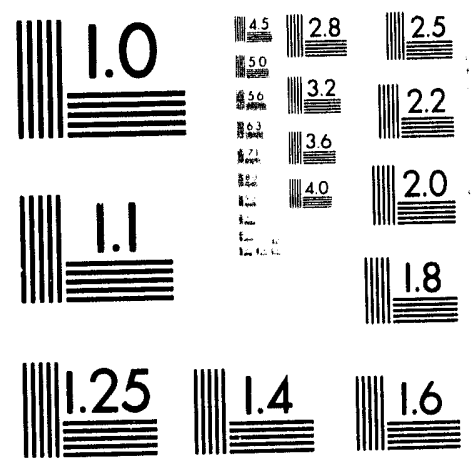



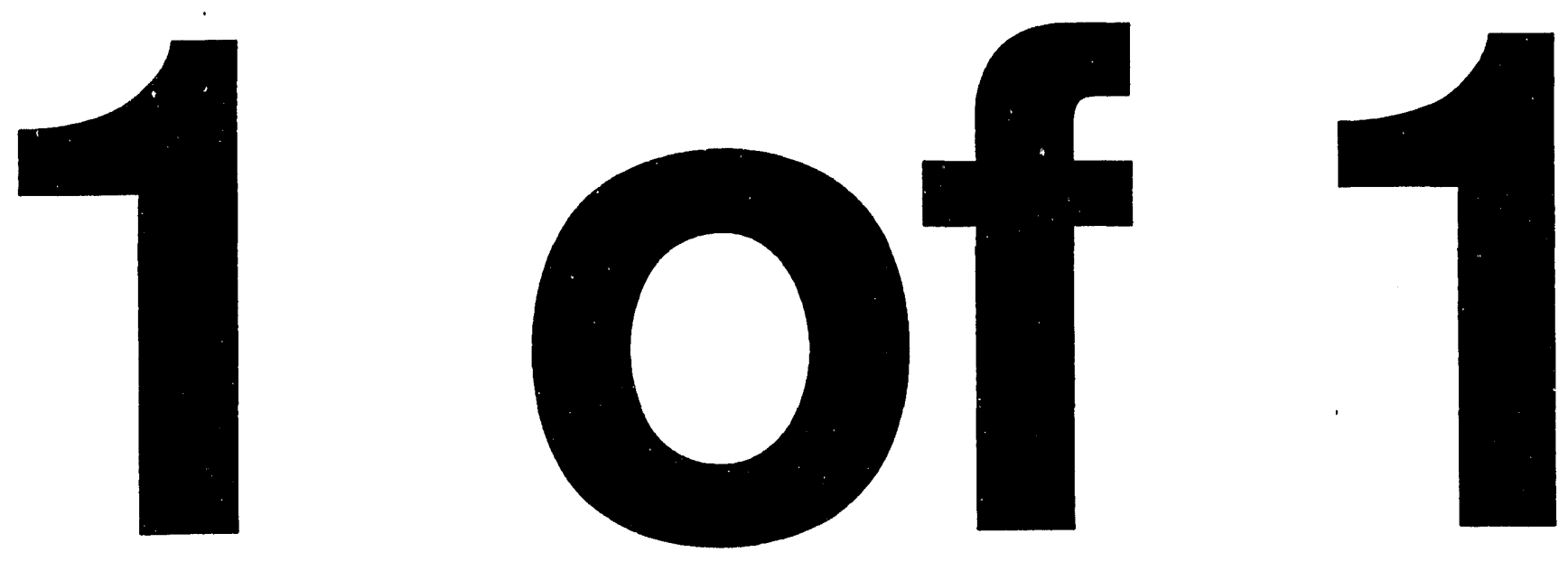
Resource Characterization and Residuals Remediation Task 1.0

Semi-Annual Report

March 1 - June 30, 1993

\section{S.B. Hawthorne}

R.C. Timpe

J.H. Hartman

July 1993

Work Performed Under Cooperative Agreement No.: DE-FC21-93MC30097

For

U.S. Department of Energy

Office of Fossil Energy

Morgantown Energy Technology Center

Morgantown, West Virginia

By

Energy \& Environmental Research Center

University of North Dakota

Grand Forks, North Dakota 


\section{DISCLAIMER}

This report was prepared as an account of work sponsored by an agency of the United States Government. Neither the United States Government nor any agency thereof, nor any of their employees, makes any warranty, express or implied, or assumes any legal liability or responsibility for the accuracy, completeness, or usefulness of any information, apparatus, product, or process disclosed, or represents that its use would not infringe privately owned rights. Reference herein to any specific commercial product, process, or service by trade name, trademark, manufacturer, or otherwise does not necessarily constitute or imply its endorsement, recommendation, or favoring by the United States Government or any agency thereof. The views and opinions of authors expressed herein do not necessarily state or reflect those of the United States Government or any agency thereof.

This report has been reproduced directly from the best available copy.

Available to DOE and DOE contractors from the Office of Scientific and Technical Information, P.O. Box 62, Oak Ridge, TN 37831; prices available at (615) $576-8401$.

Available to the public from the National Technical Information Service, U.S. Department of Commerce, 5285 Port Royal Rd., Springfield, VA 22161; phone orders accepted at (703) 487-4650. 
LIST OF FIGURES $\ldots \ldots \ldots \ldots \ldots \ldots \ldots \ldots \ldots \ldots \ldots \ldots \ldots \ldots \ldots \ldots \ldots \ldots$ ii

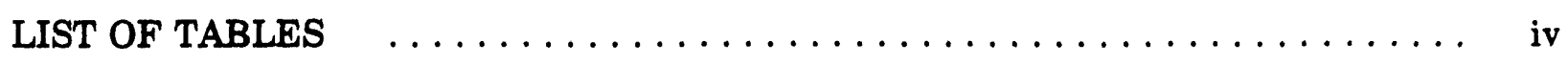

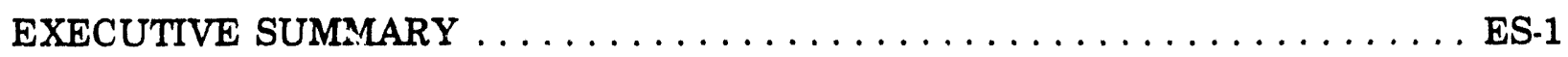

TASK 1.0 RESOURCE CHARACTERIZATION AND

RESIDUALS REMEDIATION $\ldots \ldots \ldots \ldots \ldots \ldots \ldots \ldots \ldots \ldots \ldots \ldots$

Subtask 1.1 Sulfur Forms and Thermal Transformations $\ldots \ldots \ldots \ldots \ldots \ldots$

Introduction $\ldots \ldots \ldots \ldots \ldots \ldots \ldots \ldots \ldots \ldots \ldots \ldots \ldots \ldots \ldots, 1$

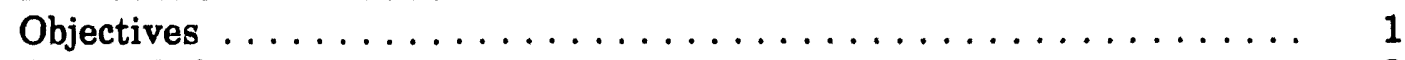

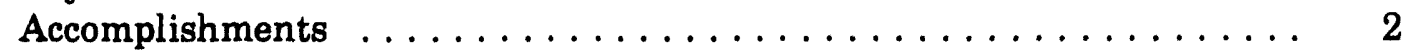

References.......................... 7

Subtask 1.3 Data Resource Evaluation $\ldots \ldots \ldots \ldots \ldots \ldots \ldots \ldots \ldots \ldots$

Introduction $\ldots \ldots \ldots \ldots \ldots \ldots \ldots \ldots \ldots \ldots \ldots \ldots \ldots \ldots \ldots \ldots, 8$

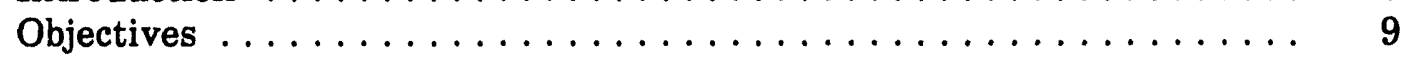

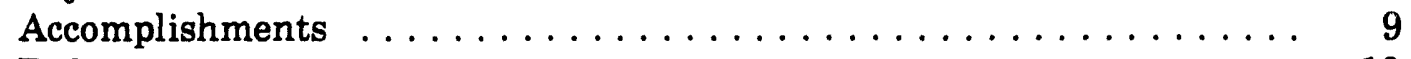

References ............................ 19 


\section{LIST OF FIGURES}

Figure

Page

1.3-1 GIS computer programming incorporates a variety of data types from a variety of sources that permit a broad spectrum approach to resource characterization and management. . . . . . . . . . . . .

1.3-2 Resource Data Evaluation study areas in western North Dakota and eastern Montana include 1) the Fort Union Corridor, 2) the Nesson Anticline (subset), and 3) the Little Missouri River-Greater Slope County (base map produced by

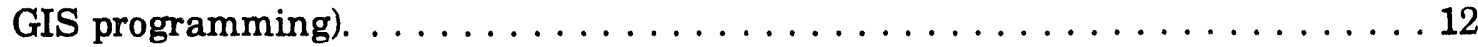

1.3-3 Dots represent coal-related geologic observations (M-numbers) along the Missouri River in portions of five counties centered on Fort Union, which represents the namesake of the Fort Union Group and the Fort Union lignite regions. The cadastral system, political boundaries, transportation, hydrology, and geologic observations are layers in a GIS file (see text)

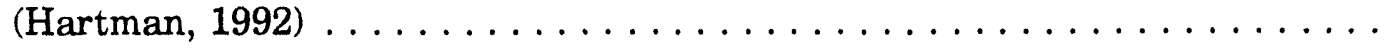

1.3-4 In the cadastral system, legal location (township and range) digital data may be purchased or digitized (a). Political boundaries (county) derived from TIGER information are shown for the area of the Nesson Anticline (b) $\ldots \ldots \ldots \ldots \ldots \ldots$

1.3-5 All transportation TIGER information available for roads is shown for the area of the Nesson Anticline (a). Another data layer available is to display major transportation routes (b)

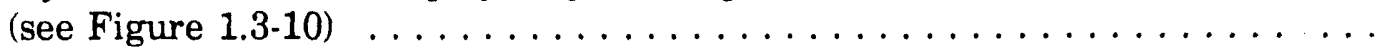

1.3-6 All subsurface drainage TIGER information available is shown for the area of the Nesson Anticline (a). Major tributaries of the Missouri River (Lake Sa'rakawea) can be chosen for display (b) (see Figure 1.3-10).

1.3-7 Digitized fossil localities are displayed in the area of the Nesson Anticline (a). Paleontologic data provide the only effective means of providing chronostratigraphic control for strata in the stidy area. Digitized surface and subsurface geologic observations can be displayed corsisting of measured and geophysical sections and spot coal identifications and thicknesses in the area of the Nesson Anticline (b) (see Figure 1.3-10) . . . . . . . . . . . . . . . . . . . 


\section{LIST OF FIGURES (continued)}

Figure

1.3-8 A digitized portion of the North Dakota State Geologic Map produced by Clayton and others (1977) is shown (a). Light and dark stippled areas represent the Bullion Creek and Sentinel Butte Formations of the Fort Union Group. Structure contour 1 displays a digitized representation of the structure contour map of the Williston Lignite bed and utilized observations on various lignite beds produced by Collier (1918, pl. XXVI), who first described and named the Nesson Anticline (b) ................................. 16

1.3-9 Structure contour 2 is a digitized representation of the Williston lignite bed, produced by Spencer (1978a, 1981), on the Nesson Anticline (a). Structure contour 3 is a map of the base of the Williston lignite bed produced by Resource Data Evaluation studies utilizing reevaluated and newly taken observations $(b)$ (see Figure $1.3-10) \ldots \ldots \ldots \ldots \ldots \ldots$

1.3-10 A structure contour map of the Williston lignite, Nesson Anticline area is displayed. The structure contour map of the base of the Williston lignite bed is overlain on a cadastral base map, with political boundaries, transportation, hydrology, and geologic observations, all layers derived from GIS programming ............................ 17 


\section{LIST OF TABLES}

Table

1.1-1 Proximate and Total Sulfur Analysis of Coal Samples IBC-101

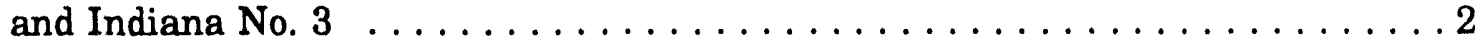

1.1-2 Sulfur in Coal Residue Samples and Sulfate Extract $\ldots \ldots \ldots \ldots \ldots \ldots$

1.1-3 Sulfur Forms Analyses of Coal Samples IBC-101 and Indiana

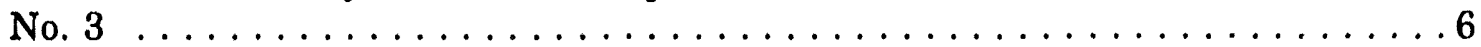

1.1-4 Percentage of Sulfur Removal from Elemental-Free IBC-101 and Indiana No. 3 with Different Supercritical Fluids $\ldots \ldots \ldots \ldots \ldots \ldots$

1.1-5 Pyrolysis/SFE Sulfur Removal from IBC-101 and Indiana No. 3 Using Supercritical $\mathrm{CO}_{2} / 10 \% \mathrm{MeOH}$ and $\mathrm{CO}_{2} /$ Phosphoric Acid . . . . . . . 7 


\section{EXECUTIVE SUMMARY}

The resource characterization and residuals remediation task embraces the beginning and the end of the energy use cycle. It provides fundamental characterization of fuel and associated resources so these can be used most effectively. Once resources have been used, any residues produced must be used and or disposed of in an environmentally compatible manner. Sulfur, for example, is widespread throughout the environment in many forms. Understanding the occurrence, transport, and fate of sulfur as it moves along energy pathways through the environment is the key to managing the environmental effects of sulfur. Subtask 1.1, Sulfur Forms and Thermal Transformations, focuses on the ability to identify and measure different fo:ms of sulfur. Progress is being made in our analytical ability to distinguish the forms of sulfur, a prerequisite to engineering management. Similarly, Subtask 1.3, Data Resource Evaluation, is focused on integrating resource characterization information on energy resources from cradle to grave in a comprehensive, integrated system. A geographic information system is being tested with a representative case used field resource data from North Dakota and Montana. 


\section{TASK 1.0 RESOURCE CHARACTERIZATION AND RESIDUALS REMEDIATION}

\section{Subtask 1.1 Sulfur Forms and Thermal Transformations}

\section{Introduction}

At present, no reliable method exists for identifying and quantitating sulfur forms in coal. The ability to reliably identify and quantitate the individual sulfur forms in different coals and coal products (including chars) is necessary to support new engineering approaches for reducing the sulfur content in coal products and emissions. Current analytical tests (ASTM D2492, D271) separate coal sulfur into pyritic (calculated from iron measurements), sulfitic, and organic (calculated by difference). Only total sulfur and sulfate (a minor fraction) are based on direct measurements. The pyritic sulfur value is subject to criticism since it is based on a measure of iron which is assumed to adhere rigidly to the stoichiometry of mineral pyrite rather than on sulfur itself. "Organic" sulfur from the ASTM method is particularly objectionable since it is a difference value and includes sulfur species that are not organic, such as elemental and sulfitic sulfur, as well as hundreds to thousands of organic compounds including (but not limited to) thiophenes, condensed thiophenes, aryl sulfides, disulfides, mercaptans, thiophenols, and polysulfides.

During the past year in the Energy \& Environmental Research Center (EERC) Chromatography Mass Spectrometry Lab a reliable supercritical fluid extraction (SFE) method for determining the elemental sulfur in coal was developed. With this method, the uncertainty in the measurement of "organic" sulfur in coal was somewhat reduced. This year, the method was published in Fuel (1). In the current year, work will progress toward developing or refining methods for determining sulfitic, pyritic, and organic sulfur more accurately.

\section{Objectives}

The current investigation continues promising work begun last year to develop a reliable, convenient analytical method for direct determination of "organic" sulfur in coal and chars. The objectives of the second year's investigation are:

- To investigate and develop the use of SFE and pyrolysis/SFE for the selective extraction of true organic sulfur forms from coal. Also, to identify and quantitate the individual sulfur organics recovered from SFE procedures.

- To develop and evaluate on ne SFE methods for pyrolysis, extraction, and analysis as needed to achieve mass balance between extracted and collected organic sulfur.

- To determine the relationship between various inorganic and organic sulfur forms using class-selective extractions, scanning electron microscopy (SEMI), and stable sulfur isotope ratio measurements.

- To evaluate and incorporate other promising sulfur speciation techniques. 


\section{Accomplishments}

- COAL

A bituminous coal, IBC-101, obtained from the Illinois Basin Coal Sample Program (IBCSP), and a washed and magnetically cleaned Indiana No. 3 coal sample from AMAX Research and Development Center were used for this investigation. All of the coal samples used in this work were ground under a stream of argon to $-75 \mu \mathrm{m}$ and stored under argon in plastic containers before use. The proximate analysis of the two coals are shown in Table 1.1-1. Work on stable sulfur isotope mass spectrometry in identifying sulfur forms in IBC-101, IBC-102, IBC-106, and IBC-107 is continuing from the past year. These coals were also extracted to determine quantitative variation in sulfate extraction between ASTM $4.8 \mathrm{M} \mathrm{HCl}$ extraction and the $1.0 \mathrm{M} \mathrm{HCl}$ extraction used by the stable isotope analysis group in Leeds, United Kingdom.

\section{- SAMPLE PREPARATION}

Elemental sulfur-free coal (1) was prepared in 5-gram quantities using a Suprex Prepmaster pump (Suprex Corp., Pittsburgh, PA, USA) under mild SFE conditions $\left(\mathrm{CO}_{2} / 10 \%\right.$ methanol, $\left.400 \mathrm{~atm}, 110^{\circ} \mathrm{C}, 100 \mathrm{~min}\right)$ and a $10.4-\mathrm{mL}$ Keystone SFE extraction cell (Keystone Scientific, Bellefonte, PA, USA). A 10-cm-long crimped stainless steel tube (1/16" OD x 1/50" ID) was attached at the outlet of the extraction cell to regulate the fluid flow (typically $1.5 \mathrm{~mL} \mathrm{~min} \mathrm{~m}^{-1}$ as pressurized fluid measured at the pump), and the extracted effluent was collected by depressurizing into a sample vial containing $3 \mathrm{~mL}$ of toluene (Optima grade, Fisher Scientific, Pittsburgh, PA, USA). The analysis of the extract was performed at regular intervals by gas chromatography with atomic emission detection (GC-AED, Hewlett-Packard Company, Avondale, PA, USA). Since no elemental sulfur was detected from extracts obtained during the final 15 minutes, quantitative removal of the elemental sulfur was assumed.

Sulfate sulfur-free coal was prepared according to ASTM D2492, an $\mathrm{HCl}$ extraction (2). Coal samples of 2 grams were extracted with boiling $4.8 \mathrm{~N} \mathrm{HCl}$, washed with water, filtered, and dried in an oven at $100^{\circ} \mathrm{C}$ for 2 hours. The sample was then stored under argon in plastic containers until used. Similarly, coal samples that were free of elemental and sulfate sulfur were obtained by performing $\mathrm{HCl}$ batch extraction on elemental sulfurfree coal samples.

TABLE 1.1-1

Proximate and Total Sulfur Analysis of Coal Samples IBC-101 and Indiana No, 3

\begin{tabular}{lccccc}
\hline Coal & $\begin{array}{c}\text { Moisture } \\
(\text { wt\%) }\end{array}$ & $\begin{array}{c}\text { Volatile Matter } \\
(\text { wt\%) }\end{array}$ & $\begin{array}{c}\text { Fixed Carbon } \\
\text { (wt\%) }\end{array}$ & $\begin{array}{c}\text { Residue } \\
\text { (wt\%) }\end{array}$ & $\begin{array}{c}\text { Total Sulfur } \\
\text { (wt\%, db) }\end{array}$ \\
\hline IBC.101 & 9.0 & 35.8 & 44.6 & 10.5 & 4.3 \\
Indiana No. 3 & 4.8 & 41.7 & 46.8 & 11.5 & 4.2 \\
\hline
\end{tabular}


Pyritic and sulfitic sulfur-free coal samples were obtained by performing $\mathrm{HNO}_{3}$ batch extractions on both raw and elemental sulfur-free coal samples in accordance with ASTM method D2492 (2). Coal samples of 2 grams were extracted with boiling $2 \mathrm{~N}$ $\mathrm{HNO}_{3}$, washed with water, filtered, and dried in an oven at $100^{\circ} \mathrm{C}$ for 2 hours. The sample was then stored under argon in plastic containers until used.

\section{PYROLYSIS/SFE}

Pyrolysis/SFE experiments were performed on 50.mg coal samples that were mixed with $50 \mathrm{mg}$ of clean sand (sea sand, Fisher Scientific). The presence of the sand prevented the bituminous coal samples from agglomerating on heating, thus preventing maximum fluid.coal contact. Premixed 10\% (v/v) methanol in $\mathrm{CO}_{2}$ (Scott Specialty Gases) was used to supply the methanol-modified $\mathrm{CO}_{2}$ for the 30 -minute extractions, unless other additives were used. Additives, including approximately $200 \mu \mathrm{L}$ of $85 \%$ phosphoric acid, ethanol, or glacial acetic acid, were spiked on the sample and then extracted using pure $\mathrm{SF} \mathrm{CO}_{2}$.

The extraction cell was pressurized to 400 atm and held under static conditions while the oven was heated rapidly at ca. $32^{\circ} \mathrm{C} \mathrm{min}-1$ to $450^{\circ} \mathrm{C}$ (requiring ca. $13 \mathrm{~min}$ ). The dynamic extraction was then begun and was continued for 30 minutes at 400 atm and $450^{\circ} \mathrm{C}$.

Following extraction, the oven was cooled to ambient temperature before the extraction cell was detached from the extraction line for safety and to prevent any possible loss of material. The entire contents of the extraction cell were collected and analyzed for total sulfur in accordance with ASTM guidelines. The extent of sulfur species removal from either untreated or treated coal feeds (expressed in percentage of sulfur removed) was determined by comparing the total sulfur content in the SFE. extracted residues (in $\mathrm{mg}$ of sulfur) with that in the untreated raw coal (in $\mathrm{mg}$ of sulfur).

To reduce the loss of extremely volatile species, on-line pyrolysis/SFE/GC-MS was used to extract 1-mg coal samples. Pyrolysis/SFE extract was collected cryogenically $\left(-50^{\circ} \mathrm{C}\right)$ at the inlet of a DB-5 GC column. Following the extraction, the condensed extract was desorbed onto the GC column and analyzed with the MS.

\section{- RESULTS}

This project involves the development of a series of procedures with which sulfur forms can be measured directly, quickly, accurately, and economically. The strategy involves removal of forms by sequential extractions and measurement of the sulfur. As the method for each form becomes available, the procedure and experimental results of the developmental work will be published in refereed journals. Two publications discussing the work completed during this reporting period are referenced $(1,3)$.

Elemental sulfur was extracted from four coals, IBC-101, IBC-102, IBC-106, and IBC-107, with supercritical $\mathrm{CO}_{2} / 10 \% \mathrm{CH}_{3} \mathrm{OH}$ at $110^{\circ} \mathrm{C}$ and 400 atmospheres. The residues were analyzed in duplicate for $\mathrm{SO}_{4}=$ by the ASTM sulfate method described in D2492. This procedure, in which $\mathrm{Ba}^{++}$is used to precipitate the $\mathrm{SO}_{4}{ }^{-}$after it has been extracted from the coal with hot $\mathrm{HCl}$, is a relatively simple, straightforward gravimetric method for directly determining that form of sulfur. To test this method and the reproducibility and to compare it with the method used by Dr. Simon Bottrell of the University of Leeds, UK, 
(Methods 1 and 2 on Table 1.1-2) for obtaining sulfur forms for stable sulfur isotope analysis in his laboratory, the coals were extracted in duplicate under air and under $\mathrm{N}_{2}$. Table 1.1-1 shows the results obtained with these extractions. Reproducibility of all duplicates was excellent. No real difference in $\mathrm{SO}_{4}-$ was observed between the results of an extraction done at a given acid strength and at a given temperature under air compared with that done under $\mathrm{N}_{2}$. Slightly more sulfate was extracted from the IBC-101 and the IBC-107 with the $4.8 \mathrm{M} \mathrm{HCl}$ (ASTM) than with the $1 \mathrm{M} \mathrm{HCl}$ (Bottrell). Total sulfur analyses of the extracted residues gave results similar to those just described for the sulfate analyses of the corresponding extract. However, when the sulfur mass balance was calculated, there appeared to be only a slight loss of sulfur in IBC-101, but a much greater loss of sulfur in the IBC-107, indicating that the $\mathrm{HCl}$ extraction is probably removing sulfur species in addition to $\mathrm{SO}_{4}{ }^{=}$and suggesting that the $\mathrm{HCl}$ extraction method is coal-specific. This has the effect of introducing a second source of error in the ASTM sulfur forms analysis, the first being the lack of determination of elemental sulfur, thus lumping it in with the "organic" sulfur value which is calculated by difference.

Traditional sulfur forms analysis yielded the results shown in Table 1.1-3. Both of these coals were high in "organic" sulfur. As a result, substantial sulfur removal from the sample, i.e., more than $35 \%$, implies a reduction in that form. Table 1.1.4 shows that a great deal more than $35 \%$ sulfur reduction occurs in all cases. The $\mathrm{H}_{3} \mathrm{PO}_{4}$ spike followed by pyrolysis/SFE removes ca. $80 \%$ of the sulfur, whereas less severe additives such as ethanol, acetic acid, and methanol followed by pyrolysis/SFE remove ca. $40 \%$ to $60 \%$.

The results shown in Table 1.1-5 using the raw, sulfate-free, and sulfate- and pyritefree coals demonstrate that both pyrolysis/SFE conditions with and without $\mathrm{H}_{3} \mathrm{PO}_{4}$ remove a substantial portion of the true organic sulfur. Assuming that the $\mathrm{HCl}$ extraction quantitatively removes sulfate and that the $\mathrm{HNO}_{s}$ extraction quantitatively removes sulfate and pyrite, the percentage of organic sulfur removed by $\mathrm{CO}_{2} / 10 \%$ methanol only, or by the addition of phosphoric acid followed by pyrolysis/SFE, can be estimated. For example, if $70 \%$ of the sulfur in IBC-101 is organic, and if $\mathrm{CO}_{2} / 10 \%$ methanol combined with $\mathrm{HNO}_{3}$ extraction removed $78 \%$ of the total sulfur (Table 1.1.4), then the minimum fraction of true organic sulfur extracted by pyrolysis/SFE with $\mathrm{CO}_{2} / 10 \%$ methanol would be $73 \%$ (78\% total sulfur removed minus $27 \%$ inorganic removed by $\mathrm{HNO}_{3}$ equals $51 \%$ of total sulfur extracted by SFE, which is equivalent to $73 \%$ of the organic sulfur removed by SFE). Similarly, pyrolysis/SFE with $\mathrm{CO}_{2} /$ methanol extracts a minimum of $70 \%$ of the true organic sulfur from the Illinois No. 3 coal.

The results shown in Table 1.1-5 also demonstrate that the addition of phosphoric acid causes the extraction of both sulfate and pyrite as well as a substantial portion of the organic sulfur. Again, if it is assumed that the $\mathrm{HNO}_{3}$ quantitatively extracts the sulfate and pyrite, the minimum fraction of organic sulfur extracted by pyrolysis/SFE with the addition of phosphoric acid would be $69 \%$ and $73 \%$ for IBC-101 and Illinois No. 3, respectively.

To determine the forms contributing to the sulfur removed by the pyrolysis/SFE, and perhaps interconversion of sulfur forms, stable sulfur isotope analysis was performed on extracts of IBC-101, IBC-102, IBC-106, and IBC-107 obtained by SFE (elemental sulfur), $\mathrm{HCl}$ extraction (sulfitic sulfur), $\mathrm{HNO}_{3}$ extraction (pyritic sulfur or, in the case of raw coal, 
TABLE $1.1-2$

Sulfur in Coal Residue Samples and Sulfate Extract

\begin{tabular}{|c|c|c|c|c|c|}
\hline & $\begin{array}{c}\text { SFE } \\
\text { Extracted }\end{array}$ & $\begin{array}{c}\mathrm{HCl} \\
\text { Extracted }\end{array}$ & Sulfate & $\begin{array}{c}\mathrm{wt} \% \mathrm{SO}_{4} \\
\mathrm{~S} \text { in Coal }\end{array}$ & $\begin{array}{c}\% \\
\text { Recovery }\end{array}$ \\
\hline \multicolumn{6}{|c|}{ Sulfur (mg) } \\
\hline \multicolumn{6}{|c|}{ Method $1\left(1 \mathrm{M} \mathrm{HCl}, \mathrm{N}_{2}\right)$} \\
\hline 101 & 74.35 & 53.76 & 11.77 & 0.57 & 88.14 \\
\hline 101 & 72.21 & 55.76 & 12.02 & 0.60 & 93.87 \\
\hline 107 & 69.31 & 52.10 & 6.27 & 0.31 & 84.22 \\
\hline 107 & 67.60 & 49.15 & 6.12 & 0.31 & 81.76 \\
\hline \multicolumn{6}{|c|}{ Method $2\left(1 \mathrm{M} \mathrm{HCl}, \mathrm{N}_{2}\right.$, heated $\left.95^{\circ} \mathrm{C}\right)$} \\
\hline 101 & 72.48 & 53.31 & 13.32 & 0.67 & 91.93 \\
\hline 101 & 72.68 & 55.60 & 12.48 & 0.62 & 93.67 \\
\hline 107 & 67.78 & 49.96 & 6.65 & 0.33 & 83.52 \\
\hline 107 & 67.78 & 50.71 & 6.29 & 0.31 & 84.10 \\
\hline \multicolumn{6}{|c|}{ Method $3\left(4.8 \mathrm{M} \mathrm{HCl}\right.$, air, heated $\left.95^{\circ} \mathrm{C}\right)$} \\
\hline 101 & 72.51 & 54.83 & 14.33 & 0.72 & 95.38 \\
\hline 101 & 72.46 & 53.00 & 13.57 & 0.68 & 91.87 \\
\hline 107 & 67.56 & 49.05 & 7.21 & 0.36 & 83.27 \\
\hline 107 & 67.60 & 49.55 & 6.94 & 0.35 & 83.57 \\
\hline \multicolumn{6}{|c|}{ Method $4\left(4.8 \mathrm{M} \mathrm{HCl}, \mathrm{N}_{2}\right.$, heated $\left.95^{\circ} \mathrm{C}\right)$} \\
\hline 101 & 72.51 & 56.41 & 12.97 & 0.65 & 95.68 \\
\hline 101 & 72.72 & 54.81 & 12.64 & 0.63 & 92.75 \\
\hline 107 & 67.74 & 49.42 & 7.15 & 0.36 & 83.51 \\
\hline 107 & 67.67 & 49.72 & 6.80 & 0.34 & 83.52 \\
\hline \multicolumn{6}{|c|}{ Method 3A (4.8 $\mathrm{M} \mathrm{HCl}$, air, boil, $\left.110^{\circ} \mathrm{C}\right)$} \\
\hline 101 & 72.68 & 57.59 & 13.59 & 0.68 & 97.94 \\
\hline 101 & 72.47 & 55.60 & 13.10 & 0.65 & 94.80 \\
\hline 107 & 67.74 & 52.84 & 6.84 & 0.34 & 88.10 \\
\hline 107 & 67.84 & 51.62 & 6.89 & 0.34 & 86.24 \\
\hline \multicolumn{6}{|c|}{ Method 3A (4.8 $\mathrm{M} \mathrm{HCl}$, air, boil, $\left.110^{\circ} \mathrm{C}\right)$} \\
\hline 102 & 51.24 & 25.37 & 20.85 & 1.04 & 90.20 \\
\hline 102 & 51.07 & 27.17 & 20.52 & 1.02 & 93.38 \\
\hline 106 & 62.41 & 42.72 & 15.83 & 0.79 & 93.82 \\
\hline 106 & 62.14 & 40.19 & 16.11 & 0.80 & 90.60 \\
\hline
\end{tabular}

pyritic and sulfitic coal), and Canfield extraction (pyritic sulfur). The results were not conclusive, and additional study is in progress on the isotope technique as well as the data obtained.

- Future work includes the following:

- To determine a method of improving sulfur closure following $\mathrm{HCl}$ extraction

- To continue to develop a method for selective extraction of pyrite 
- To compare the results obtained with the Canfield extraction technique with those of the ASTM D2492 $\mathrm{HNO}_{3}$ extraction

- To extract and identify organic sulfur species

TABLE 1.1-3

Sulfur Forms Analyses of Coal Samples IBC-101 and Indiana No. 3

\begin{tabular}{lcccc}
\hline & \multicolumn{4}{c}{ ASTM "Organic" S } \\
\cline { 2 - 5 } & Sulfitic (wt\%) & Pyritic (wt\%) & Organic (wt\%) & Elemental (wt\%) \\
\hline IBC-101 $^{1}$ & 16 & 11 & 70 & 2.5 \\
${\text { Indiana No. } 3^{2}}^{2}$ & 19 & 11 & 66 & 4.0 \\
\hline
\end{tabular}

1 Average values of sulfur forms analysis performed by Minnesota Valley Testing Laboratories and Huffman Laboratories, Inc.

2 Average values of sulfur forms analysis performed by Minnesota Valley Testing Laboratories, Huffman Laboratories, Inc., and AMAX.

3 Values detarmined using the method in Reference 3.

TABLE 1.1.4

Percentage of Sulfur Removal from Elemental-Free IBC-101 and Indiana No. 3 with Different Supercritical Fluids

\begin{tabular}{lcc}
\hline & \multicolumn{2}{c}{ Percentage of Total Sulfur Removed } \\
\cline { 2 - 3 } SF Fluids/Reagent & IBC-101 & Indiana No. 3 \\
\hline $\mathrm{CO}_{2}$ & $49 \pm 1$ & $\ldots$ \\
$\mathrm{CO}_{2} / \mathrm{MeOH}$ & $62 \pm 3$ & $60 \pm 7$ \\
$\mathrm{CO}_{2} /$ Acetic Acid & $43 \pm 2$ & $\ldots$ \\
$\mathrm{CO}_{2} /$ Ethanol & $48 \pm 1$ & $\ldots$ \\
$\mathrm{CO}_{2} / \mathrm{H}_{3} \mathrm{PO}_{4}$ & $82 \pm 3$ & $78 \pm 9$ \\
\hline
\end{tabular}

1 Standard deviations are based on triplicate, 30-minute extractions.

2 Not determined. 
TABLE 1.1.5

Pyrolysis/SFE Sulfur Removal from IBC-101 and Indiana No. 3 Using Supercritical $\mathrm{CO}_{2} / 10 \% \mathrm{MeOH}$ and $\mathrm{CO}_{2} /$ Phosphoric Acid

\begin{tabular}{lcccc}
\hline & \multicolumn{3}{c}{ \% Sulfur Removal on Total Sulfur Basis } \\
\hline & \multicolumn{2}{c}{$\mathrm{CO}_{2} / \mathrm{MeOH}$} & \multicolumn{2}{c}{$\mathrm{CO}_{2} /$ Phosphoric Acid } \\
\cline { 2 - 5 } Coal Samples: & IBC-101 & Indiana No. 3 & IBC-101 & Indiana No. 3 \\
\hline Raw & $62 \pm 3$ & $60 \pm 7$ & $82 \pm 3$ & $78 \pm 9$ \\
Sulfate-Free & $70 \pm 1$ & $72 \pm 1$ & $83 \pm 13$ & $85 \pm 23$ \\
$\mathrm{~S}_{8}$-/and $\mathrm{SO}_{4}$-Free & $68 \pm 1$ & $68 \pm 2$ & $81 \pm 12$ & $84 \pm 7$ \\
$\mathrm{SO}_{4}-\mathrm{FeS}_{2}$-Free & $78 \pm 1$ & $76 \pm 3$ & $78 \pm 13$ & $81 \pm 12$ \\
$\mathrm{~S}_{8}-\mathrm{SO}_{4}, \mathrm{FeS}_{2}$-Free & $81 \pm 2$ & $72 \pm 4$ & $80 \pm 11$ & $74 \pm 10$ \\
\hline
\end{tabular}

1 Standard deviations are based on triplicate, 30-minute extractions.

\section{References}

1. Louie, P.K.K.; Timpe, R.C.; Hawthorne, S.B.; Miller, D.J. Fuel 1993, 72, 225.

2. Annual Book of ASTM Standards, Vol 05.05, Gaseous Fuels: Coal and Coke; ASTM, Philadelphia, PA, 1991.

3. Louie, P.K.K.; Timpe, R.C.; Hawthorne, S.B.; Miller, D.J. "Sulfur Removal from Coal by Analytical-Scale Supercritical Fluid Extraction (SFE) under Pyrolysis Conditions," Presented at the Coal Utilization and the Environment Meeting, Orlando, FL, May 1993; Fuel 1993, June 2, in review. 


\section{Subtask 1.3 Data Resource Evaluation}

\section{Introduction}

The long-term objective of the Resource Data Evaluation project is the development of methods that incorporate all of the fundamental aspects of resource characterization, utilization, and reclamation within a single integrated system. This project will approach its objective through the use of Geographic Information Systems (GIS) technologies as a data management tool. The project with evaluate and select GIS programming and provide initial demonstration of its utility in ongoing projects, to be followed by implementation of the system within the energy and environmentul research programs at the EERC.

Advances in computer hardware and software technology are reshaping the approach to data acquisition, management, and analysis. Importantly, data sharing, or data availability, has become an important outcome of the increase in agencies and institutions striving for an integrated approach to resolving the myriad of complex global concerns. At the vanguard of the integrative technologies is an approach known as GIS. GIS is a software technology that permits the input, manipulation, analysis, and display of geographically referenced data. As such, GIS represents a set of tools to perform a variety of functions directed toward integrating both map information and associated attribute data. The portrayal and analysis of such information can occur at many levels of specificity. Many traditional map-oriented endeavors, from geology to city planning, are well suited for use in GIS programming. The strength of GIS utility, however, is in its capability to integrate and portray the relationship between data typically left unassociated due to the lack of a means to bring different types of information into one format and method of analysis (say for example the cost relationship between geology and urban sewer systems). The final display of information for the user is no longer the major and costly task of a project, freeing the user to explore alternative approaches to understand the relationship between data of different types. Investigation, not compilation and display, thus becomes (or remains) the central research issue. The ongoing development of GIS software is analogous (but at a tremendously greater level) to the advent of sophisticated word processing or spreadsheet programming. The clerical responsibility is no longer just the production of typed error-free reports, but the manipulation of information to produce publication-quality documents.

GIS may be best thought of as a method of analysis that supports the decisionmaking process of an organization. The question "what if" is likely to be explored to great advantage employing GIS technology. The interpretation of the relationship of different social concerns, such as topography and land use, coal quality and utilization, or air emissions and pollution, are important to effective resource management, but are not traditionally easily related as single issues or together as a complex of problems. The various types of analytical procedures available to the GIS user would be difficult to employ in traditional map making. The conversion of qualitative observations to coded digital information makes data generally available for any number of applications as each data type is treated as a separate layer within GIS programming. The clear advantage of GIS technology is the ability to edit (i.e., revise or add) information in each layer independently and to relate these layers easily, to produce, in a relatively straightforward manner, a new generation of maps specific to current needs and applications. Existing attribute data can be uploaded to be utilized in GIS applications. Derived data and 
geographic locations can be downloaded for use in other graphical, analytical, data management, or word processing programs.

\section{Objectives}

The Resource Data Evaluation initiative consists basically of two component projects that represent a single objective, which is to develop an understanding of the analysis capabilities across the spectrum of program areas at the EERC to support data management needs as part of the decision-making process. These program areas include energy and environmental policy and planning, mine planning and reclamation, energy resource occurrence, groundwater resource occurrence, and waste management studies.

In Project 1, Resource Data Integration, research is directed toward the development of an approach to fully integrate a geographically based resource management system to interpret the complex relationships between capability, utilization, and reclamation. The integration of resource data across the large number of energy and environmental concerns requires specialized programming and hardware specific to the information. intensive applications of multilayered attribute data associated with GIS. Commercially available geographical information system software will be utilized with advanced computing systems as the data management system to analyze these relationships. Research will focus on the methodology and system requirements to undertake a sequence of pilot projects.

In Project 2, Resource Data Correlation, research is undertaken to apply GIS technologies by example to determine programming and $h_{1}$.rdware requirements to utilize a variety of data types. Examples include research areas in the Paleocene age coalbearing strata of the Williston Basin in North Dakota and adjacent areas in Montana. The objective of this project is to utilize existing EERC databases to integrate coal-related information with geologic information for the specific purpose of summarizing the status of coal bed recognition and correlation in the Williston Basin. Tasks will be directed toward the publication of outcrop area and regional syntheses of Paleocene stratigraphic units for the purpose of a comprehensive nomenclature guide for the Williston Basin portion of the Fort Union lignite area. This information will provide a tool specifically designed for earth resource evaluation and characterization, but will also have applications for groundwater and environmental concerns by providing the means of defining bed and other lithesome correlations in specific areas.

\section{Accomplishments}

The proposed research included a number of activities that were thought to represent a comprehensive approach to fully develop geographic information systems capabilities at the EERC. The interest in utilizing a GIS technology strategy to problem solving and data management has, however, mushroomed between the time the research was proposed and work commenced. The value of a GIS approach does not appear to need to be argued. Researcher interest is in how GIS can be applied to researcher's data and what needs to be done for the system to become operational. How to facilitate becoming functional in GIS is and will remain the major hurdle toward GIS purchases. Major concerns include potential acquisition of costly software and hardware, training of current or additional staff, getting current data into a GIS mode, and the expense of maintaining the system. As the personal computer has taken the place of many mainframes, minis, 
and micros for many computing needs, will the intensive number crunching associated with GIS programming require more powerful machines and knowledge of different operating systems?

The Resource Data Evaluation project undertook test cases to determine by example how to apply GIS to various coal resource projects ongoing at the EERC. By way of example, one test case is presented here and will involve the GIS basics illustrated in Figure 1.3-1. The Fort Union Corridor of the Missouri River, North Dakota-Montana (Figures 1.3-2 and 1.3-3) is a project area that includes the surface and subsurface stratigraphic records for northern McKenzie and southern Williams Counties, North Dakota, and northern Richland and southern Roosevelt Counties, Montana. The Fort Union Corridor, as defined by the study, extends from about New Town, North Dakota, to Culbertson, Montana. This area effectively includes the type area of the Fort Union Group, representing the Fort Union coal region, and includes the coal-bearing strata of the Paleocene age Bullion Creek (= Tongue River) and Sentinel Butte Formations. Previous research in the area computerized the location of numerous geologic observations into databases designed and maintained in $\mathbf{Q} \& \mathbf{A}^{\bullet}$ by Symantec Corporation. All of these observations had previously been ploited, as specifically as possible, on 1:24,000-scale U.S. Geological Survey (USGS) topographic quadrangles. For the purposes of this test case, version 2 of Atlas GIS by Strategic Mapping, Inc., was selected to determine (at least the initial) utility of a PC-based GIS program. Atlas GIS was run without difficulty on a 486 Gateway 2000 (4DX2-66V) computer with $8 \mathrm{MB}$ of RAM. Output was directed to a Hewlett Packard LazerJet III with $3 \mathrm{MB}$ of memory (see figures), as well as to other programming (discussed below). The point locations, representing about 400 surface and subsurface geologic observations (Figure 1.3-3), were digitized using a 24- x 36-inch GTCO Corporation Digi-Pad type $5 \mathrm{~A}$ with a 16 -button cursor and 0.001 " resolution.

A smaller field study area was selected to deal specifically with the correlation of coal beds and formational contacts. The area of the Nesson Anticline (Figure 1.3-2) was chosen because of the known difficulty of correlating significant coal beds in this area and the attendant lack of consistency on placing the Bullion Creek-Sentinel Butte formational contact (Hartman and others, 1993). The Nesson Anticline was first recognized and delimited by Collier (1918) by producing a structure contour map of the Williston lignite bed. The proposed research would attempt to resolve the problems of correlation across the Nesson Anticline utilizing Atlas GIS and additional field observations.

As noted above, the management of map-based information in GIS programming is on the basis of treating discrete information types as distinct layers (files) that can be layered as desired. Figures 1.3-4 through 1.3.9 represent a succession of layers derived though the course of the test case of the Nesson Anticline. The cadastral base map for this project was digitized from the USGS quadrangles covering the area (Figure 1.3-4). Township and range digital map (DLG) files for these quadrangles could have been purchased either from the U.S. Geological Survey or from a secondary vendor, such as the North Dakota Geological Survey. Added map information, including political (county) boundaries (Figure 1.3-4), roads (Figure 1.3-5), and hydrologic (Figure 1.3-6) were obtained and derived from U.S. Census Bureau TIGER files available on CD-ROM. Political boundaries of various types are also frequently available as part of software packages, but may vary in quality. The amount of transportation and surface drainage information in TIGER files is enormous. Figure 1.3-5 illustrates all of the digitized roadways, which, except for State Highway 1804, are all graveled. By compositing desired line segments, 


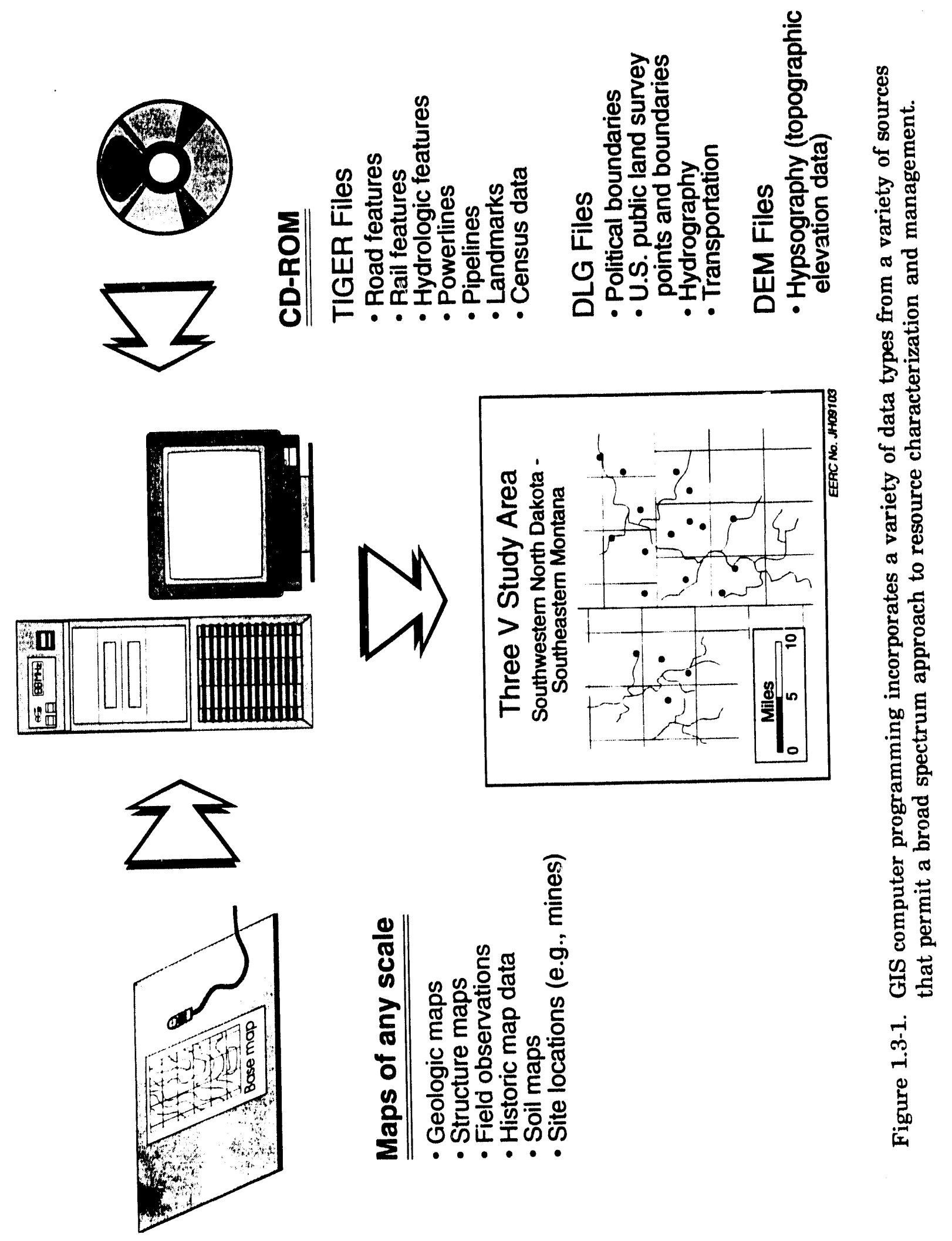




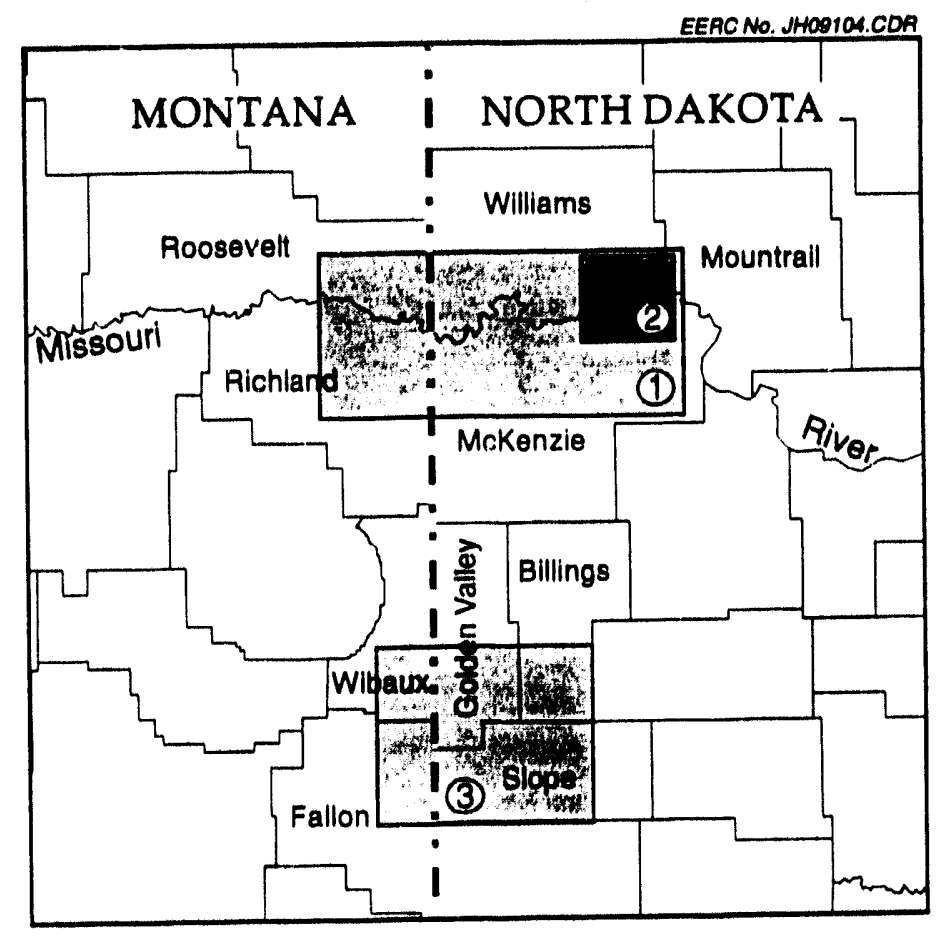

Figure 1.3-2. Resource Data Evaluation study areas in western North Dakota and eastern Montana include 1) the Fort Union Corridor, 2) the Nesson Anticline (subset), and 3) the Little Missouri River-Greater Slope County (base map produced by GIS programming).

most of which are only a few tenths of a kilometer in length, the roadways of interest can be selected and illustrated (Figure 1.3-4b). Similarly, there are only a few important tributaries of the Missouri River (here as Lake Sakakawea), and these were selected (Figure 1.3-6b) from the tremendous detail provided by the TIGER files (Figure 1.3.6a).

The previously digitized geologic observations represent their own layer (Figure 1.3-7b). They are illustrated here as pluses (on circles) and circles, representing subsurface and surface geologic sections. To provide chronostratigraphic control to the strata of the Nesson Anticline, fossil localities were also digitized from 1:24,000-scale USGS maps to illustrate their geographic distribution (Figure 1.3-7a). Again, this information is represented as a separate layer with its own associated attribute information. For both geologic and paleontologic observations, once the location of the locality was digitized and associated with the unique number representing the occurrence (M-numbers and L-numbers, respectively), attribute information was uploaded from databases maintained in $Q_{\& A}{ }^{\oplus}$ (by Symantec Corporation), through a dBase ${ }^{\oplus}$ (Borland International, Inc.) export utility filter in $Q \& A^{\oplus}$. Likewise, longitude and latitude derived from Atlas GIS were downloaded into EERC databases. 

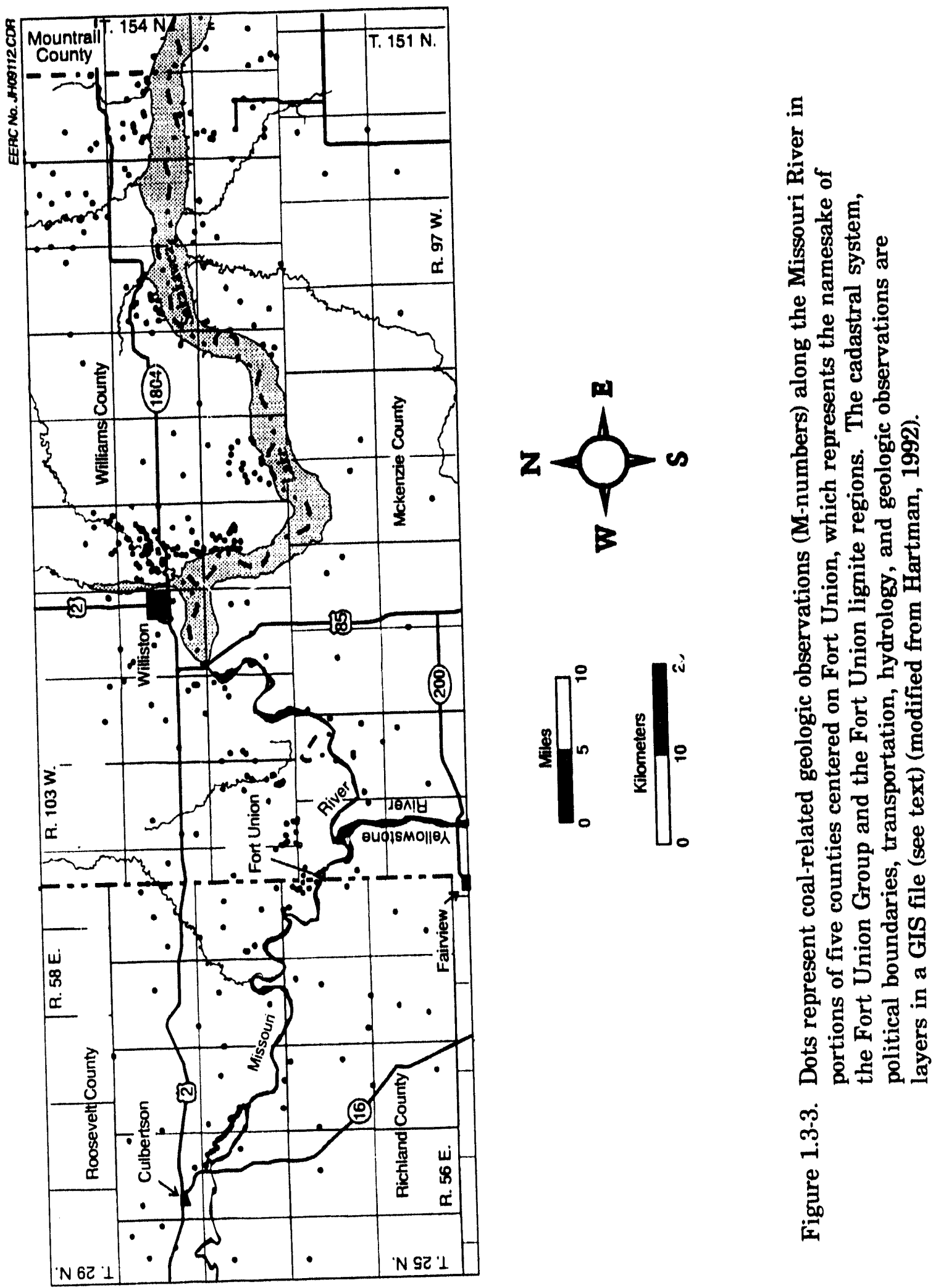


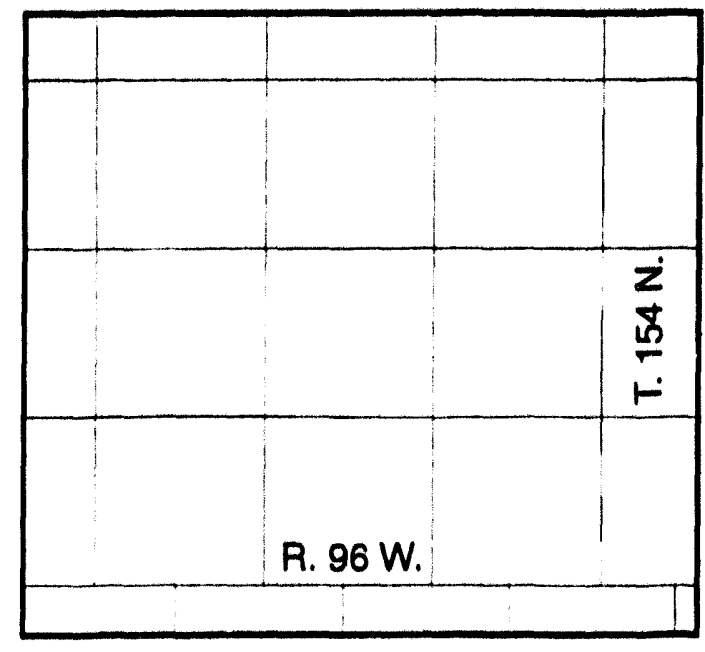

(a)

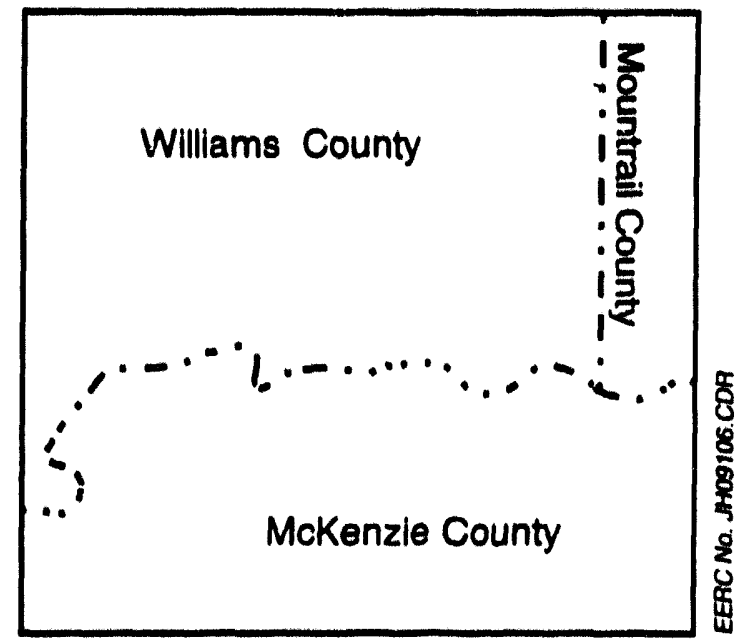

(b)

Figure 1.3-4. In the cadastral system, legal location (township and range) digital data may be purchased or digitized (a). Political boundaries (county) derived from TIGER information are shown for the area of the Nesson Anticline (b).

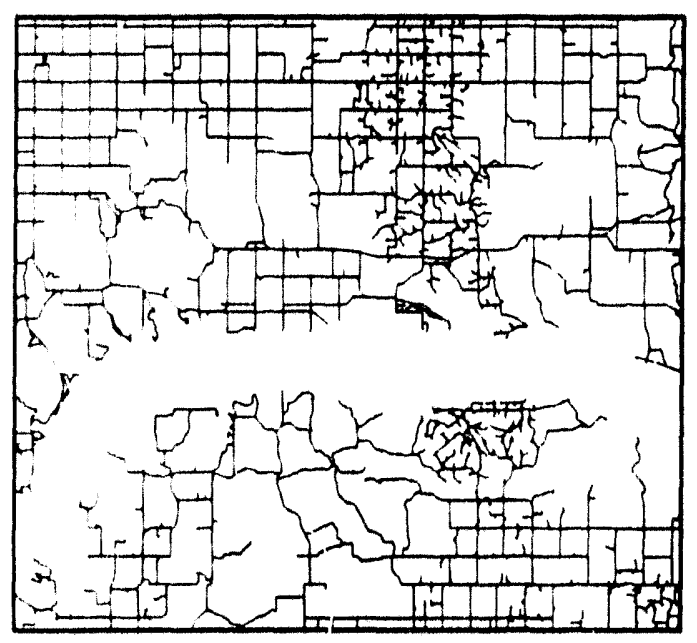

(a)

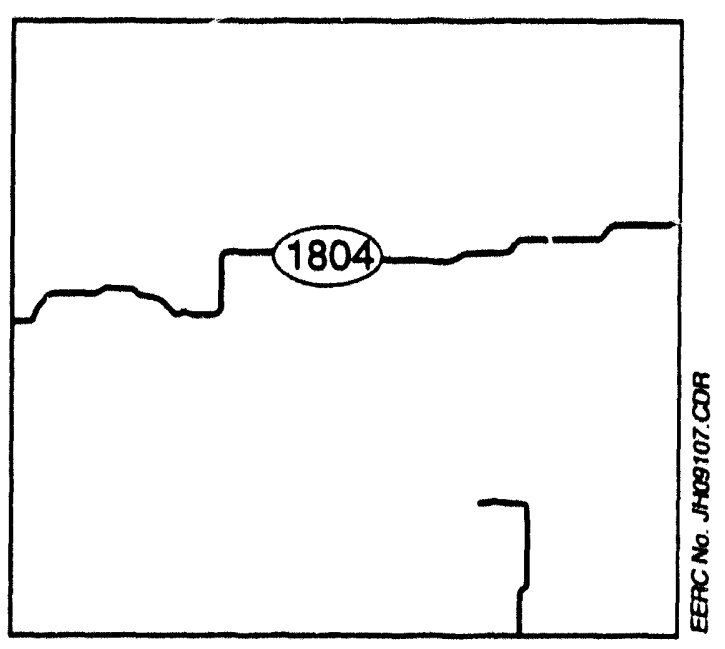

(b)

Figure 1.3-5. All transportation TIGER information available for roads is shown for the area of the Nesson Anticline (a). Another data layer available is to display major transportation routes (b) (see Figure 1.3-10). 


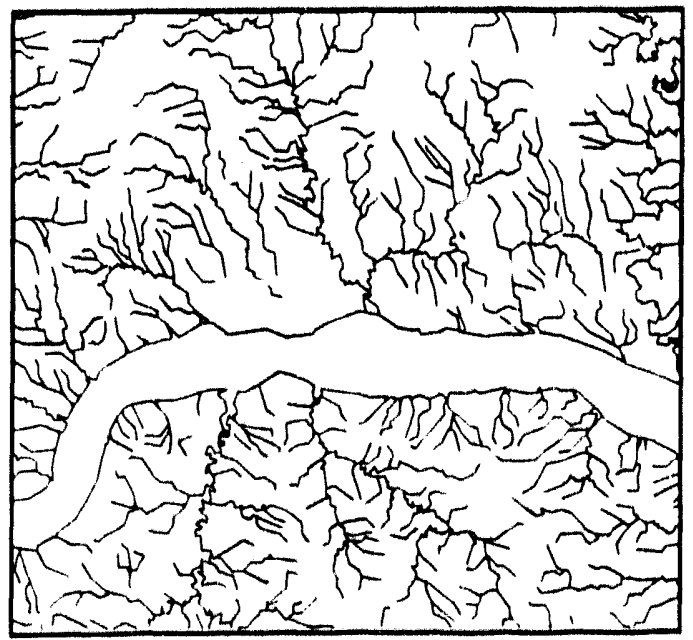

(a)

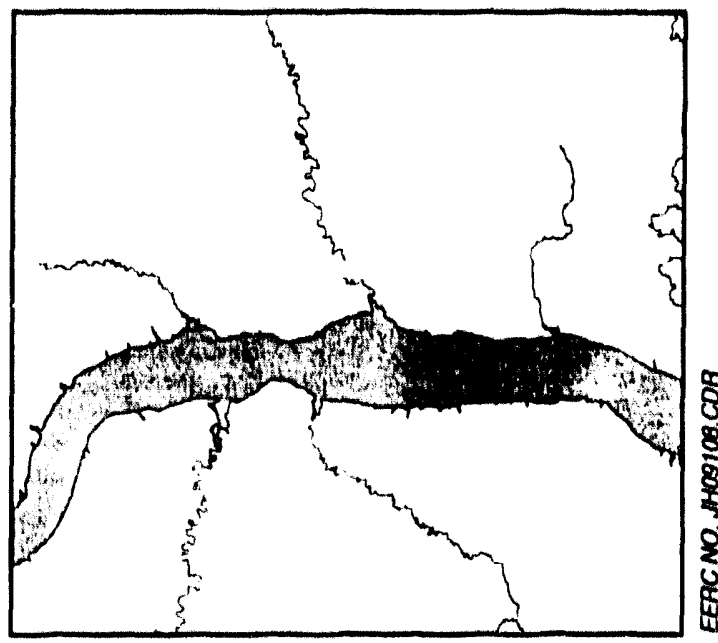

(b)

Figure 1.3.6. All subsurface drainage TIGER information available is shown for the area of the Nesson Anticline (a). Major tributaries of the Missouri River (Lake Sakakawea) can be chosen for display (b) (see Figure 1.3-10).

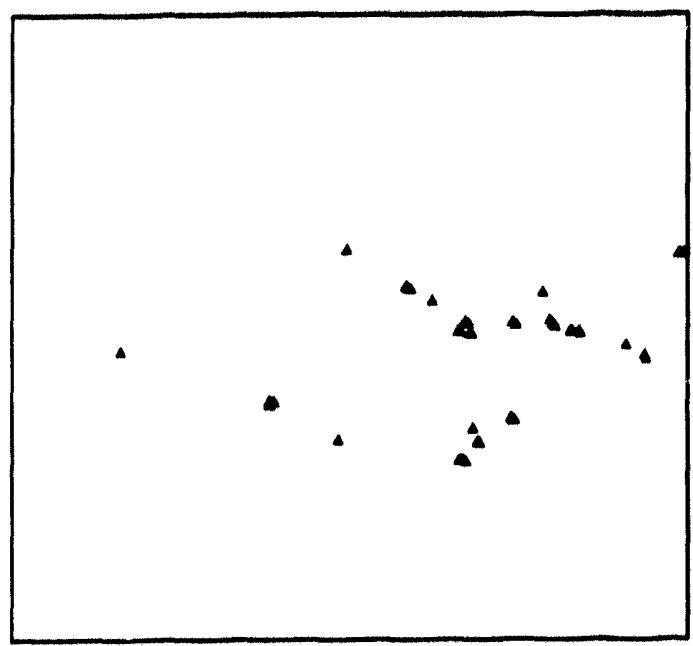

(a)

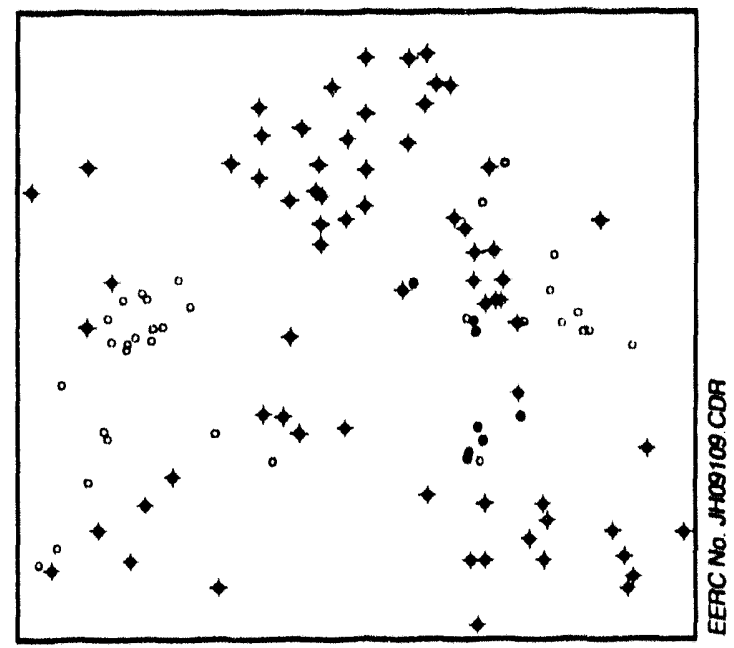

(b)

Figure 1.3-7. Digitized fossil localities are displayed in the area of the Nesson Anticline (a). Paleontologic data provide the only effective means of providing chronostratigraphic control for strata in the study area. Digitized surface and subsurface geologic observations can be displayed consisting of measured and geophysical sections and spot coal identifications and thicknesses in the area of the Nesson Anticline (b) (see Figure 1.3-10). 


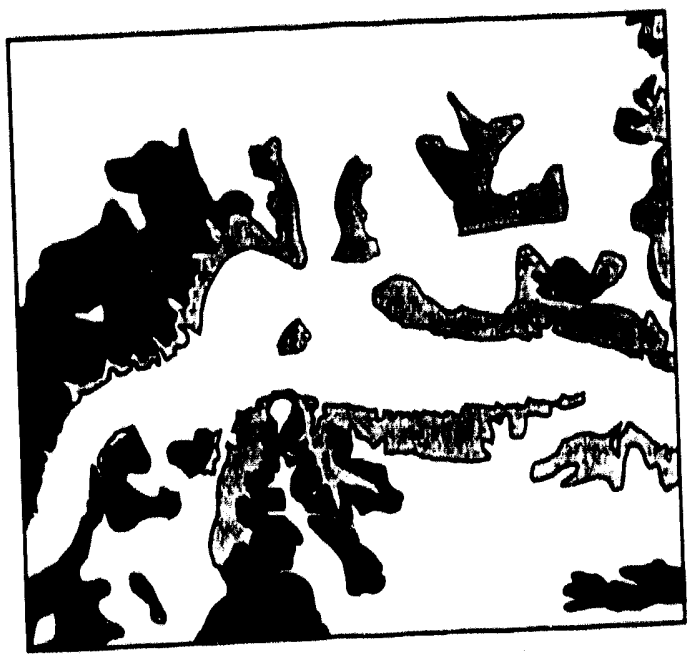

(a)

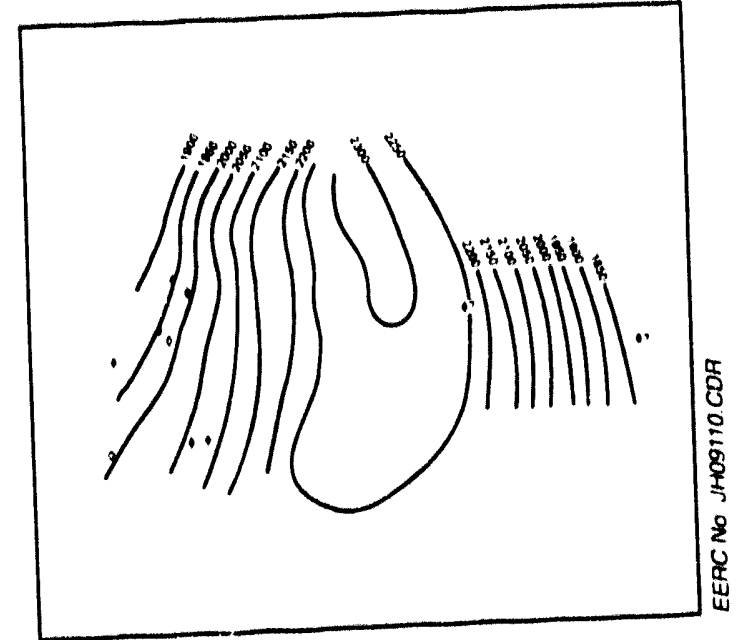

(b)

Figure 1.3.8. A digitized portion of the North Dakota State Geologic Map produced by Clayton and others (1977) is shown (a). Light and dark stippled areas represent the Bullion Creek and Sentinel Butte Formations of the Fort Union Group. Structure contour 1 displays a digitized representation of the structure contour map of the Williston Lignite bed and utilized observations on various lignite beds produced by Collier (1918, pl. XXVI), who first described and named the Nesson Anticline (b).

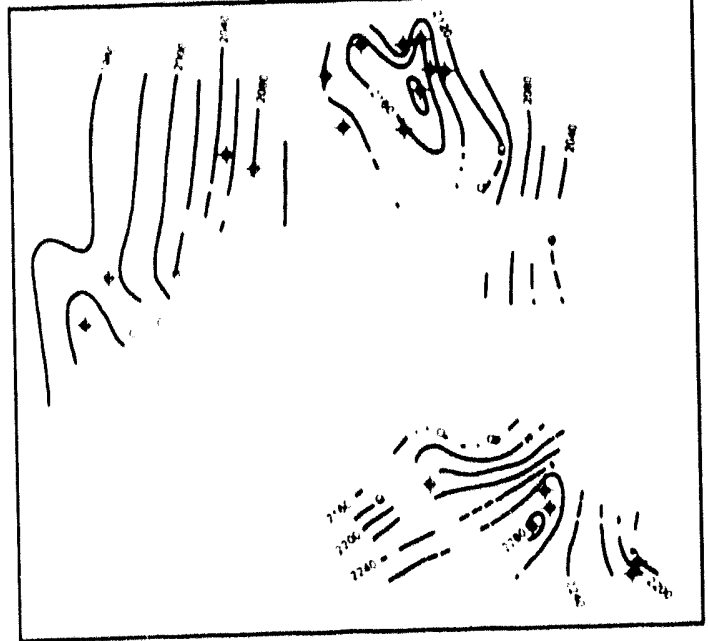

(a)

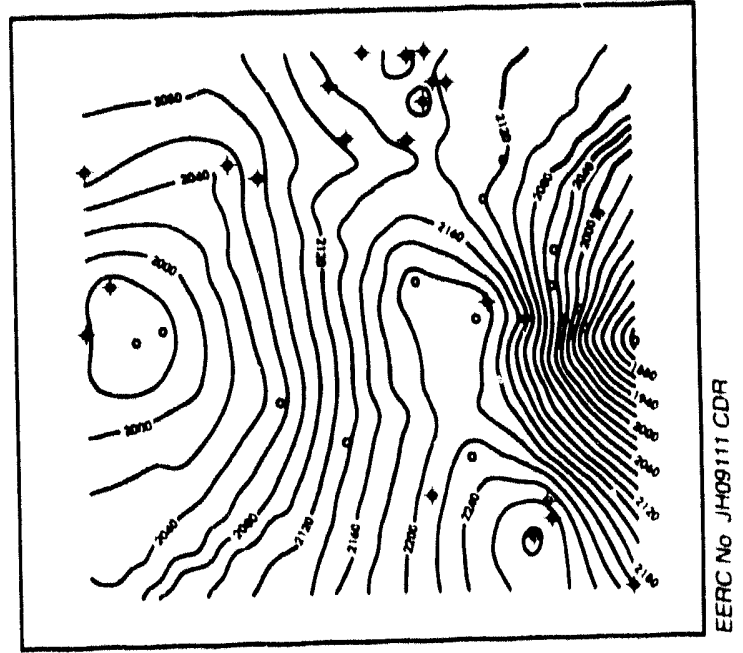

(b)

Figure 1.3.9. Structure contour 2 is a digitized representation of the Williston lignite bed, produced by Spencer (1978a, 1981), on the Nesson Anticline (a). Structure contour 3 is a map of the base of the Williston lignite bed produced by Resource Data Evaluation studies utilizing reevaluated and newly taken observations (b) (see Figure 1.3-10). 


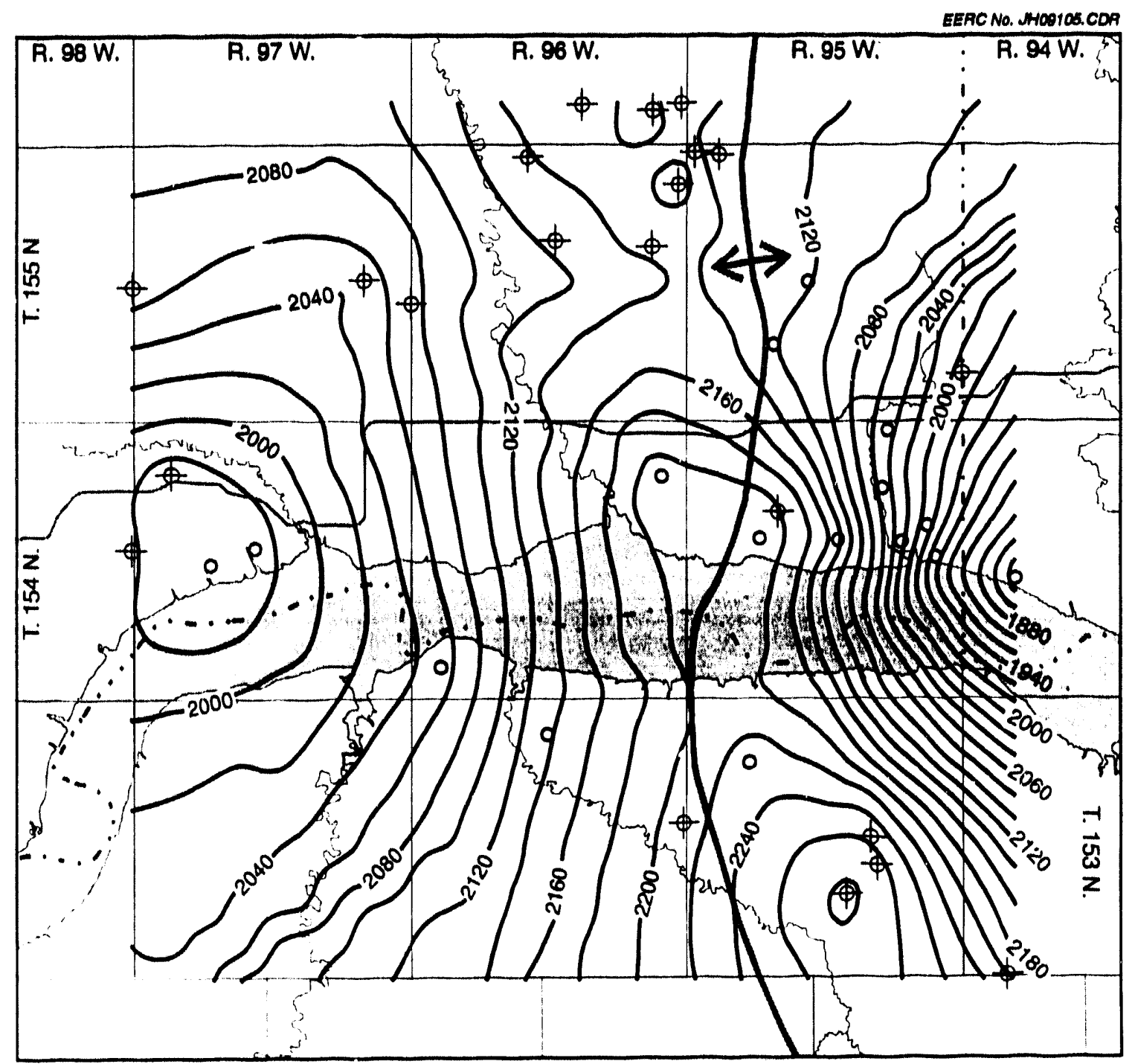

Contour Interval $=20 \mathrm{ft}$
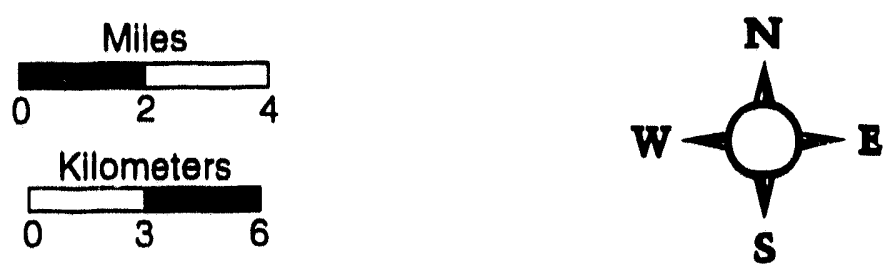

Figure 1.3-10. A structure contour map of the Williston lignite, Nesson Anticline area is displayed. The structure contour map of the base of the Williston lignite bed is overlain on a cadastral base map, with political boundaries, transportation, hydrology, and geologic observations, all layers derived from GIS programming. 
Previous surficial geologic studies in the area of the Nesson Anticline disagreed as to the placement of the Bullion Creek-Sentinel Butte formational contact (Nevin, 1946; Royse, 1967a,b; Spencer, 1978a,b; Spencer, 1981; Clayton and others, 1980a; Carlson, 1985). Although the relative placement of the contact was known to be different among these workers, establishing the criteria, both literally and as portrayed on maps and in sections, needed to be determined. Where geologic maps were produced (as with Royse, Spencer, Clayton, and Carlson), their map data were digitized into Atlas GIS. An example of the transfer of geologic map units from the North Dakota State Geologic Map (Clayton and others, 1980a) is presented in Figure 1.3.8a. The light and dark stippled units represent the Bullion Creek and Sentinel Butte Formations, respectively. Other geologic maps were ligitized and layered for comparison. Of interest and importance, all of the maps, representing map scales of 1:100,000, 1:250,000, and 1:500,000, were all originally produced with such care as to permit very precise registration to the cadastral base map and TIGER file data. From a sequence of overlays, the approximate relative stratigraphic position of the respective Bullion Creek-Sentinel Butte formational contact could be derived at certain control points.

The correlation of the Williston lignite bed, as well as other coal beds, was treated by earlier workers, but without consensus as to its identification on ine east flank of the Nesson Anticline and in the badland breaks on the south side of the Missouri River. To understand and reinterpret previous records of the Williston lignite bed, the structure contour maps produced by Collier (1918) and Spencer (1978a, 1981) were digitized (Figures 1.3.8b and 1.3-9a). The map produced by Collier (Figure 1.3.8b) was generalized on a few observations on the north side of the Missouri River on the west flank of the Nesson Anticline. Coal bed observations recorded on the south side of the river are for other coal beds. The placement of the Williston lignite bed by Collier (1918) was based on an extrapolation of the relative stratigraphic thickness between these other beds and the Williston, which at best were known from only a few observations. The correlation of the Williston lignite bed by Spencer $(1978 \mathrm{a}, 1981)$ is represented in Figure 1.3-9a and shows a different structural configuration for the crest of the Nesson Anticline on either side of the Missouri River. The Williston lignite bed is believed to be partly inaccurately identified on the south side of the river.

A revised structure contour interpretation of the relative elevation of the Williston lignite bed is presented in Figure 1.3.9b. This map was constructed from a reevaluation of all of the previously measured surface and subsurface geologic sections in the area of the Nesson Anticline and to the west towards Williston, in the area of its reference section. Additional sections were measured on both sides of the Missouri River by Hartman, Peck, and Kihm, of Minot State University, to serve as controls. Using all available data, the form of the Nesson Anticline is clearly illustrated in Figure 1.3-9b, with the west flank forming a more gentle dip slope than the east (downriver). This diagram was constructed by contouring the elevations of the base of the Williston lignite bed. Such a contour map cannot be made directly in Atlas GIS, which indicates an important limitation in its analysis capabilities. The elevation and geographic location data were exported to and contoured in version 4 of SURFER ${ }^{\star}$ by Golden Software, Inc.

Once contoured, the map image was saved as a DXF file and imported into version 3 of CorelDRAW ${ }^{\star}$ by Corel Corporation. The layered cadastral (Figure 1.3-4a), political boundaries (Figure 1.3-4b), selected roads (Figure 1.3-5b), selected hydrology (Figure 1.3.6b), and observations on the Williston lignite bed (derived from Figure 1.3.7b) were 
exported from Atlas GIS and imported into CorelDRAW ${ }^{\circ}$ as a CGM file. The control and registration of the Atlas GIS derived data in CorelDRAW ${ }^{\circ}$ is precise, and each of the GIS layers can be treated independently. The contour map produced in SURFER ${ }^{\bullet}$ is added as a layer and registered. The final product is illustrated as Figure 1.3-10. Although relatively high-quality maps can be produced directly irom Atlas GIS and a laserjet printer, significant graphical capabilities are added by the use of such programs as CorelDRAW ${ }^{\bullet}$. Final maps produced in CorelDRAW ${ }^{\bullet}$ were outputted to a Matrix PRC film recorded (by Agfa) to make slides for presentations (Hartman and others, 1993; and in-house GIS presentations).

The above steps illustrate a basic simple utility of GIS programming. Both the advantages and limitations of certain specific programs indicate that acquisition and testing of more analysis-oriented programming may be of value. However, the relative power of a PC-based GIS program is clearly evident in maintaining geographically based information from a variety of sources, representing a number of different map scales, produced originally for different purposes spanning many years of research effort.

In summary, a GIS approach to data management will become integral to any research undertaking that requires the synthesis of information across disciplines. The proviso that this information be map-oriented, that is, tied to a point or area on the earth, encompasses essentially all but the most conceptual problems. A GIS approach, however, is more complicated in its relational data management and more expensive than many other tools in a computer's arsenal to manipulate information. The market for GIS is changing rapidly as many local, state, and federal agencies commit to a strategy of managing the resources under their charge through GIS technologies. With this commitment, new opportunities will exist that permit a far greater utilization of existing information and thus provide a means for more rigorous and soundly based resource decisions.

\section{References}

Carlson, C.G., 1985, Geology of McKenzie County, North Dakota: North Dakota Geological Survey, Bulletin 80, pt. 1, 48 p., 5 pls.

Clayton, Lee, Carlson, C.G., Moore, W.L., Groenewold, G.H., Holland, F.D., Jr., and Moran, S.R., 1977, The Slope (Paleocene) and Bullion Creek (Paleocene) Formations of North Dakota: North Dakota Geological Survey, Report of Investigations No. 59, $14 \mathrm{p}$.

Clayton, Lee, Mcran, S.R., and Bluemle, J.P., and Carlson, C.G., 1980a, Geologic map of North Dakota, 1:500,000: North Dakota Geological Survey, 1 sheet (see Clayton and others, 1977; and Clayton and others, 1980b).

Clayton, Lee, Moran, S.R., and Bluemle, J.P., 1980b, Explanatory text to accompany the geologic map of North Dakota (1:500,000): North Dakota Geological Survey, Report of Investigations No. $69,93 \mathrm{p}$.

Collier, A.J., 1918, The Nesson Anticline, Williams County, North Dakota: U.S. Geological Survey Bulletin, v. 691-G, p. 211-217, pl. XXVI. 
Hartman, J.H., 1992, Coal correlation and chronostratigraphy of the type area of the Fort Union Group, Fort Union coal region, western North Dakota, in Energy \& Environmental Research Center, 1992 Annual Report, July 1, 1991, through June 30, 1992: p. 231-238.

Hartman, J.H., Peck, W.D., and Kihm, A.J., 1993, Paleocene stratigraphy of the Nesson Anticline: Placement of the Bullion Creek-Sentinel Butte formational contact:

North Dakota Academy of Science (1993 Annual Meeting), v. 47, p. 49.

Nevin, Charles, 1946, The Keene Dome, northeast McKenzie County, North Dakota:

North Dakota Geological Survey Bulletin, v. 21, pt. I, p. 1-10, 1 pl.

Royse, C.F., 1967a, A stratigraphic and sedimentologic analysis of the Tongue River and Sentinel Butte Formations (Paleocene), western North Dakota [Ph.D. thesis]: Grand Forks, University of North Dakota, 312 p.

Royse, C.F., 1967b, The Tongue River-Sentinel Butte contact in western North Dakota: North Dakota Geological Survey, Report of Investigations No. 45, 53 p.

Spencer, J.M., 1978a, Lignite geology of southeast Williams County, North Dakota: U.S. Geological Survey, Open-File Report 78-168, 12 p, 13 pl.

Spencer, J.M., 1978b, Geophysical and lithologic logs for 1977 coal drilling in McKenzie County, North Dakota: U.S. Geological Survey, Open-File Report 78-451, 161 p.

Spencer, J.M., 1981, Lignite geology of the Keene area, McKenzie County, North Dakota: U.S. Geological Survey, Open-File Report 81-602, 8 p., 8 pls. 

